\title{
Engaging with patronage and corruption in a corona-defined world
}

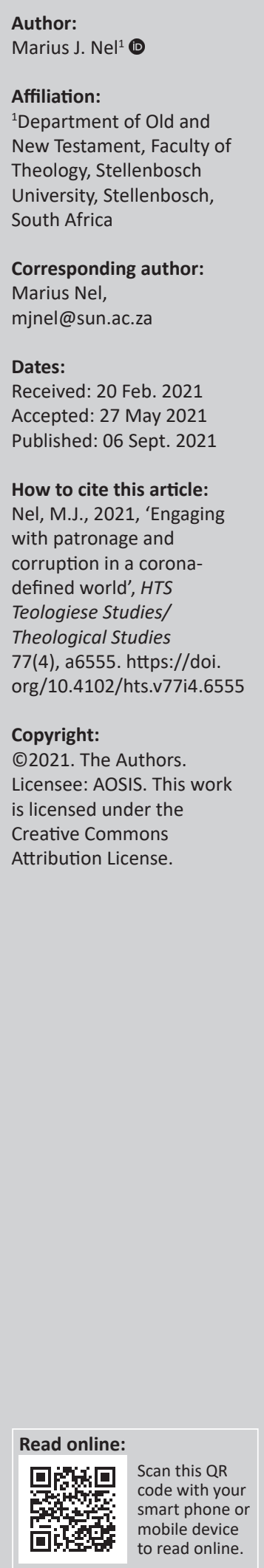

The background of this article is the ethical challenges presented by patronage that has been highlighted by the present coronavirus disease 2019 (Covid-19) pandemic. The aim of the article is to understand the role patronage plays in Africa from the perspective of a relevant African hermeneutic. Like many studies undertaken in an African setting, it uses a comparative methodology to create a dialogue between a socio-historical textual analysis of the biblical text and the socio-economic and religio-cultural realities of African contexts. It specifically uses an analogical paradigm that compares the reception of the biblical tradition in a specific historical critical context to its reception in modern-day African contexts. The result of the comparison is that the misuse of patronage is engaged from the perspective of the response of early Christian writers to patronage in the 1st century. This initial exploration has indicated that an analogous comparative approach has the potential to provide deeper insights in understanding the relationship established by patronage in African contexts. The conclusion is that in its engagement with patronage in Africa, the church must encourage its members to ask if it establishes parasitic or exploitative relations, if it is beneficial to the whole society over an extended period of time and if a clear distinction is made between public (offices) and personal resources. Ultimately, it needs to be asked if benefaction reflects the will of God and enhances the reputation of the congregation of God.

Contribution: The contribution of the article is in clarifying the potential analogical comparisons for studying the Bible in Africa and for the formulation of a critical African ethic.

Keywords: patronage; African biblical studies; corona-defined; corruption; benefaction.

\section{Introduction}

The coronavirus disease 2019 (Covid-19) pandemic has highlighted different ethical challenges that need to be urgently addressed. This article will reflect on the challenge posed by the embodiment of faith in view of the corruption that plagued the South African government's response to the Covid-19 pandemic. It will specifically focus on how the role patronage played in it should be understood from the perspective of a relevant African hermeneutic. Because of the limited scope of this article, it will not undertake a detailed analysis of all aspects involved in this engagement. It will instead survey some of the aspects that need to be taken into consideration in future studies. The premise of this survey is that the sociological investigation of the New Testament, supplemented by cultural-anthropological studies, has identified the typical roles, values and cultural matrices of meaning of the ancient world in which it was written (DeSilva 2004:124). This has enabled New Testament scholars to gain a deeper insight of the world in which the New Testament originated. Furthermore, many of these sociology insights into human relationships and the social changes that shape a society, such as perceptions of limited good, dyadic personality types, the role of kinship, honour and shame values and patron-client relationships, can be compared to those in analogous African contexts.

The focus of this article will be on patron-client relationships because of the honouree's seminal work on this topic. A selection of New Testament texts will be surveyed to ascertain how these texts engaged with patronage in the socio-historical world in which they were written to identify possible heuristic guidelines for how African ethicist could respond to the challenge posed by patronage in their contexts. It will begin by providing a brief introduction to African biblical studies and a succinct definition of patronage, before examining a selection of New Testament texts' response to patronage in their socio-historical contexts. It will conclude by undertaking an analogous comparison between the various New Testament responses to patronage with how scholars have responded to patronage in different African contexts.

Note: Special Collection: From timely exegesis to contemporary ecclesiology: Relevant hermeneutics and provocative embodiment of faith in a Corona-defined world - Festschrift for Stephan Joubert, sub-edited by Willem Oliver (University of South Africa). 


\section{African biblical studies}

A relevant hermeneutics and provocative embodiment of faith in a corona-defined world in an African context must reflect on how the Bible has been used in African biblical studies. In this regard, African biblical studies have been described as mainly following a comparative paradigm in which biblical motifs are compared with African motives in a manner that attempts to illuminate both (Holter 2002:88). In undertaking these comparisons, African biblical scholarship often choses specifically to bring socio-historical textual analysis in dialogue with the socio-economic and religiocultural realities of African contexts (West 2008:47). In pursuing a comparative approach, African biblical scholarship is overt about the life interest that invites dialogue with the Bible (West 2008:54-55). The dialogue is, however, not undertaken merely to validate that the African sociocultural world is similar to the socio-historical world in which the biblical text was created in that it is often highly critical of African phenomena (Jonker 2018:75; Masenya 2016:5).

In pursuing a comparative approach, African biblical scholarship has engaged critically with the interpretive process itself (West 2008:54-55). In reflecting on the interpretive process, Jonker (2018:77), for example, has remarked that greater care should be taken about the mode with which the comparative model establishes the link between biblical texts and the African contexts. In his estimation, many African biblical scholars are not always adequately aware that the biblical texts are constructed realities that are in dialogue with the socio-historical circumstances within which they were written (Jonker 2018:83). Jonker therefore proposes an analogical paradigm that takes the world(s) behind the biblical text into consideration (Jonker 2018:81). In an analogical paradigm, the African contexts are not compared directly to that of biblical contexts. It is rather the reception of the biblical tradition in a specific historical critical context that is compared to its reception in modern-day African contexts. This is important because the world constructed in a text can differ significantly from the world in which it was composed. Therefore, the comparison with the African context (the world in front of the text) should not only be with the constructed world (the world in the text) but also with the world in which the text was composed (the world behind the text). ${ }^{1}$

West (2018:247) had stated that while most examples of African biblical hermeneutics can be described as following a bi-polar approach in which the African contexts and the biblical texts interpret each other in a straightforward comparative approach, it is more accurate to describe them

1.The approach suggested by Jonker is similar to how Masenya (2016:5) understands Ukpong's vision for African biblical interpretation: 'In Ukpong's opinion, exegesis is not to be done for its own sake. The past of the biblical text is studied with a view to not to be done for its own sake. The past of the biblical text is studied with a view to seeing the kind of light it might throw to the present day ordinary people's contexts. A reader who is critically aware of a contemporary context enters the text whose context he/she is aware of, allowing the text to evoke appropriate responses, reactions and commitments in the readers context. The social-cultural contexts of both the contexts that produced the texts as well as those of the present day African ordinary people are thus brought to bear on each other, with a view to the transformation of the lives of the present day ordinary people'. as being tri-polar because they often intentionally utilise a pole of appropriation that mediates between them. This third pole that determines how the poles of text and context are brought into dialogue is ideological-theological in nature with West (2018:248), identifying at least six intersecting, yet different, emphases: inculturation, liberation, feminist, psychological, postcolonial and queer biblical hermeneutics. In this article, African postcolonial and inculturation hermeneutics will be explored as an intersectional mediating pole of appropriation. The aim of African postcolonial biblical hermeneutics is to challenge the hermeneutical and conceptual hegemony of Western biblical interpretation by interpreting the Bible through the use of African philosophy and customs to promote an African ethos (Ukpong 2001:11). Inculturation hermeneutics is a complementary contextual hermeneutic methodology that makes communities of ordinary people and their social-cultural contexts the subject of interpretation of the Bible by using the conceptual frame of reference and the involvement of 'ordinary' people in the interpretation process (Ukpong 2002:12).

\section{Definition: Patron-client relations}

Moxnes (1991:242) defines patron-client relations on a high level of abstraction succinctly as 'social relationships between individuals based on a strong element of inequality and difference in power', while Joubert (2000:23; Joubert 2001:19) provided an extended definition of patronage as a 'pervasive, voluntary form of interaction between socially disproportionate individuals, as well as between socially disproportionate individuals and groups involved in a reciprocal exchange of material goods and services'. According to these definitions, patron-client relations arise because of the exchange of different and unequal resources. In these exchanges, the patron provides economic and social resources needed by a client who responds with appropriate acknowledgements of loyalty to the patron that increase his or her honour (Moxnes 1991:242).

Patronage incorporates phenomena such as gift giving, friendship and nepotism and involves a recognisable imbalance of power in the relationship between the respective parties (e.g. Emperors and client-kings) (Crook 2012:60). It creates informal agreements in which the expectations and obligations between patrons and their clients are socially enforced with no formal contacts between them (Crook 2012:79). It is the personal nature of patron-client relations, along with its inherent imbalance of power, which makes them susceptible to exploitation and corruption (Crook 2012:61; Joubert 2001:19). While all gifts in the ancient world had strings attached (Richards 2011:260), anthropologist believe that this is applicable to all societies because there is no true altruistic giving in any society because all gifts trigger a response or a feeling of obligation (Graycar \& Jancsics 2017:1015). Fundamentally humans, whether living in ancient or modern economies, belong to the species homo reciprocus - they give nothing away without the expectation of receiving something in return (Joubert 1999:1022). For this reason, while various expressions of patronage differ in 
detail, they are alike enough on a higher level of abstraction of gift-giving that different responses to patronage can be compared analogically without thereby postulating a historical relationship between the phenomena being compared.

\section{Text: The New Testament response to patronage and benefaction}

The New Testament clearly engages with the pervasive system of patronage in the Greco-Roman world in which it originated. It is evident, for example, from Paul's careful response to monetary donations, and his explicit references to

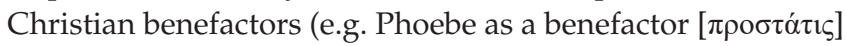
in Rm 16:1-2), that reciprocity, as it was practised in the Roman system of patronatus, was known to him (Joubert 1999:1029, 1035). It can thus be asked how the system of patronage was evaluated ethically by him and the other writers of the New Testament who were aware of the practice.

Joubert (2001:17), along with other social scientist, historians and biblical scholars, has studied various forms of dependency relations that are established and maintained through gift exchanges. Joubert's (2000) study, 'Paul as benefactor: reciprocity, strategy and theological reflection in Paul's collection', in particular, highlights the characteristics of different systems of patronage described in the extant Greek and Latin literature. This is important because sociological approaches to the New Testament have indicated that the 1st-century Mediterranean world view is not identical to the modern Western world view (Richards 2011:248). It is therefore important to interpret the New Testament in terms of the socio-historical context in which it was written (Barton 2002:277).

In his letter to the Galatians, Paul presents the congregation in Jerusalem as benefactors of the churches that he had established because they had responded positively to the testimony that he had proclaimed the gospel to the Gentiles (G1 2:6-10). In response to this benefaction, which had placed him, and the Gentiles churches under an obligation to respond appropriately to the congregation in Jerusalem, Paul had heeded Peter's plea that they should not forget the poor

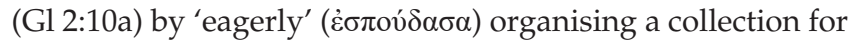

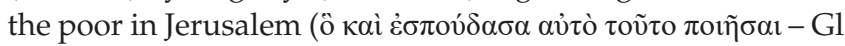
$2: 10 \mathrm{~b})$. In his letter to the Galatians, he does not depict this response to the benefaction of the congregation in Jerusalem as the settling of a debt in an agonistic relationship. He instead frames it as a response to a request from a friend (Joubert 1999:1030-1031). In Romans 15:25-27, Paul also indicates through his use of the verb củooké (Rm 15:27) that the collection by the Gentiles was not a legal requirement that they fulfilled or an 'ecclesial tax' they had to pay to the congregation in Jerusalem. It was instead the fulfilment of a moral obligation (cf. his use of ópsí $\lambda \omega$ in verse 27) to respond adequately to their benefaction. Their benefaction of spiritual gifts had thus established a relationship between the congregation in Jerusalem and the churches Paul had founded (Joubert 1999:1032).
In evaluating the New Testament author's response to patronage in its context, it should be taken into consideration that benefaction and patronage were linked to the quest for honour in the ancient world in that it was an important way with which to increase one's ascribed honour (Crook 2012:68). While benefactions could be personal in nature occurring between two individuals, many were public in that wealthy benefactors provided access to the essential services they controlled in various cities (Joubert 2001:18). They, for example, provided the financial means for the maintenance and improvement of cities' public works, purchased grain that was then sold at a lower price, paved streets, assisted cities in times of need, installed marble facades, overhauled theatres and widened roads (Winter 1994:37). It is thus a question how the early Christian writers viewed public benefaction. Winter (1994:37) has in this regard proposed that wealthy Christians after their conversion continued to act as benefactors of their respective cities. He finds support for his proposal in Romans 13:3 and 1 Peter 2:15. The reference in Romans 13:3 to the praise ("̈ंalvo $)$ ) that Christians in Rome will receive indicates to Winter (1994:34) that Paul was assuring them that the civic authorities would respond appropriately to their continued benefaction by praising them. This praise was not for a benefit that believers had provided privately to each other, but for a public deed of benefaction. This is evident from epigraphy, in which $\tau$ ò $\alpha \gamma \alpha \theta$ óv ('the good') refers to a public benefit, namely 'the good that someone does' (Winter 1994:35). The praise

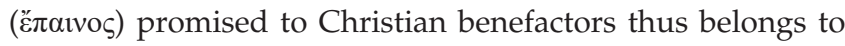
the sphere of public life. The context also suggests this for how would civic leaders in Rome (Rm 13:4) or Asia Minor (Pt 1) know what good deeds believers have performed for each other in their personal, private sphere (Winter 1994:37)? A city like Rome would also not praise minor acts of interpersonal assistance. 1 Peter 2:15 also provides a motivation for why Christians had to act as public benefactors: it is the will of God and the public tribute they received would negate the false accusations levelled against them (Winter 1994:39).

It is thus apparent that patronage as system was not seen as being inherently corrupt and thus simply to be condemned. The question therefore arises if there are differentiations made in the way patronage was evaluated from an ethical perspective on a lower level of abstraction. In this regard, Paul does provide guidelines for personal benefactions. In Romans 5:7, Paul mentions 'a good person' for whom someone would

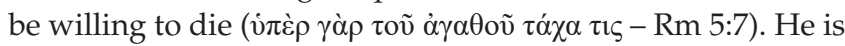
here probably referring to a believer's personal benefactor in that a client could be under an obligation to act towards his or her benefactor with gratitude even if it costs them their life. This does, however, not mean that clients should allow themselves to be exploited by their benefactors. They should instead consider the character of their benefactors and avoid exploitative benefactors (Winter 1994:42). Christian clients should also strive to become benefactors of others rather than be dependent on them. Whislt not all believers could afford to act as public benefactors, Paul in Romans 13:4 specifically addresses individuals in Rome (cf. the use of the second person singular pronoun $\sigma u$ ) who were wealthy enough to act as benefactors (Winter 1994:37). 
A possible example of Christians living as dependants, or clients, of others is the reference Paul makes to believers in Thessalonica who had stopped working. The traditional view that this was because of an immanent eschatological expectation is questioned by Winter. For him, it appears that the problem of not working was present in the congregation from the beginning because Paul writes in 1 Thessalonians

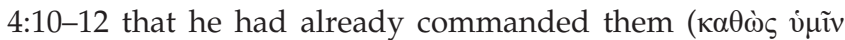
$\pi \alpha \rho \eta \gamma \gamma \varepsilon i ́ \lambda \alpha \mu \varepsilon v-T h 14: 11 b$ ) to provide for themselves. He thus mentioned it before his first extant letter was written after he had received their questions about the Second Coming. 2 Thessalonians 3:10 also refers to how Paul and his men, when they were in Thessalonica, had indicated that only those who were willing to work should eat (Winter 1994:43). Their instructions hint that providentia (the dependence on a benefactor's care) prevailed in the congregation before Paul visited it. Winter furthermore makes it clear that the rich forged client relationships only with those who belonged to the same class as them. Paul is thus not writing to the poor who depended on rich patrons to survive. Paul's recipients were instead of a higher socio-economic status. Paul, according to Winter (1994:43-44), was thus not addressing Christians who had become unemployed during the famine of $51 \mathrm{CE}$ but rather Christians who had chosen to remain in their previous client-benefactor relationships. For Paul, this parasitic conduct was contrary to the Christian way of life.

Cultivating patrons for benefits is, however, not prohibited under all circumstances in the New Testament. While the author of Luke-Acts, for example, is at times ambiguous in his depiction of patronage (cf. Lk 16:1-13), both his writings are addressed to Theophilus, whom he calls 'your Excellency'

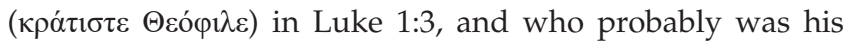
patron (Burrus 2009:142). The author of Luke is thus not indisposed to a wealthy patron supporting his work. For him, patronage is simply the way his society functions. Not only did various brokers such as governors, tribunes, centurions and soldiers represent Roman power in his world, but Jewish client kings and a priestly elite negotiated Roman power by collaboration where necessary while clinging to their independence in some matters. In this context, all Roman public functionaries, from local municipal administrators to the emperor himself, were expected to use their influence to bestow beneficial on their family and friends (Saller 1982:245). Even though every benefaction created a differentiation in status on an interpersonal and collective level (Joubert 1999:1023), it was not necessarily seen as evidence of bribery, graft or injustice. Provincials in the Roman Empire were, for example, legally entitled to show their gratitude through gifts to the governor while public inscriptions, publicising the governor's patronage, make it clear that provincial officials were expected to play a patronal role (Sell 1998:32).

In the extensive patron-client system of the Roman Empire, brokers acted as mediators between parties, for example, between Rome and the territories they had conquered or cities and its surrounding rural areas that did not have direct access to the central government (Moxnes 1991:245). Besides geographical reasons that made it impossible for patrons to deal directly with their clients, the social distance between the two was at times also too great (e.g. between the Emperor and certain officials), and therefore, the service of a broker was needed (Crook 2012:72). In these cases, the brokers are both clients of the patrons who occupy a higher social position and patrons for those who seek their help (Crook 2012:73). In the world of Luke, everyone has patrons and brokers. Examples in Luke identified as brokers by Moxnes (1991:252-254) are the centurion in Capernaum (Lk 7:1-10) and characters in Lukan parables (Lk 12:42-46; 16:1-9; 19:1127). Luke even mentions that Jesus had wealthy female patrons (Lk 8:2-3) along with those with more modest means like Martha (Lk 10:38-42) who supported his ministry (Burrus 2009:142-143).

The engagement with patronage by the New Testament authors in their contexts should, however, not be considered uniformly positive. Scholars like Scott (2007:111-112) considered some New Testament passages to be highly critical of the whole system of patronage. Scott interprets Matthew 20:1-15, for example, in which the owner of a vineyard pays labourers hired at different intervals the same wage, as upending the entire Roman patron-client system that dominated 1st-century Palestine (Scott 2007:111-112; Van Eck \& Kloppenborg 2015:2). Patronage was also part of an oppressive system of social control. Freed slaves and their children, for example, remained under the permanent power (potestas) of their former masters (Joubert 2001:19). Even euergetism, though beneficial to a city and its citizens as a whole, was practiced by an elite who considered themselves to be superior to the plebs (Joubert 2001:17) with the result that the honour they received for their benefactions would have enhanced their sense of superiority. Mbamalu (2013) in this regard argued that it is noteworthy that according to the fourth gospel, Jesus was a broker who subverts:

[T] he popular notions of patronage and affirms that true patronage as an asymmetrical relationship is about service rendered on behalf of the weak, poor or people of lower status to form a fictive kinship relationship. (p. 8)

\section{Reflection on the early Christian engagement with patronage}

In reflecting on how various writers of the New Testament evaluated patronage in their context, it is apparent that they did not condemn it outright. They instead engaged with it. It is important to note this engagement with patronage as it is considered a form of corruption from a contemporary Western perspective, the destruction of the entire system itself can have dire consequences for societies. MacMullen (1990:ix, 169-170), for example, attributes the decline of Rome to a loss of power in the state and of control over the empire's resources because of its privatisation. The privatisation of the empire entailed that all assistance from the powerful was available for those with money. This diminished the need for the patron-client relationships that had sustained communities in the past. In a privatised empire, each purchase was a complete transaction so that before it and after, no one owed anybody anything. This exchange of money for goods, 
unlike in patronage, established no long-term relationships based on obligation or honour (MacMullen 1990:169).

It was also not only Christian writers who wrote on the nature and ethics of both patronage and benefaction. GrecoRoman Philosophers also reflected it. According to Seneca (Ben. 1.4.2), for example, the giving and responding appropriately to a benefit (a favour, service or kindness) is what holds a society together (Joubert 1999:1023). In his De beneficiis, he states that the giving must be selfless. Benefits must be gifts and not investments (I.1.9, II.34.1), while the recipients must also be chosen carefully (I.1.2; II.18.3-8) in that they should be honest, grateful and not greedy (IV.11.1) (Joubert 1999:1026). While Crook (2012:62) has argued that Seneca's work should be understood as prescriptive because it does not describe an actual practice but rather an ideal, it remains an important source for understanding how GrecoRoman philosophers reflected on the practice of patronage. It is apparent from it that Seneca wanted to transform the giving of a benefit into a virtue that is in itself a reward unrelated to the response of the recipient (Joubert 1999:1026).

While Joubert (1999:1035) has indicated that even though Paul provides new Christian content for the system of patronage, he is not always consistent in the manner he does it, an attempt can be made to formulate questions based on what he and other writers in the New Testament highlight in their engagement with the practice of patronage in their socio-historical context. These questions can then be used as heuristic aids by biblical scholars in their analogous engagement of patronage through a relevant postcolonial and inculturation hermeneutic. For a provocative embodiment of faith in a corona-defined world, the following needs to be asked of occurrences of patronage:

1. Is the relationship that is established by patronage a negative one that it is parasitic (resulting in clients who do not work) or exploitative (leading to patrons who enrich themselves at the expense of others)?

2. Is patronage practiced in a manner that is beneficial to the whole society (but especially the poor) over an extended period?

3. Is a clear distinction made between public (offices) and personal spheres (friends) or are they interwoven like in the 1st-century Greco-Roman world?

4. Does benefaction reflect the will of God and enhance the reputation of the congregation of God?

\section{Context: Patronage, COVID-19 and corruption in Africa}

In a blog addressed to the citizens of South Africa on the 3rd of August 2020, President Ramaphosa (2020) announced that:

$[A]$ special centre has been established that brings together the Financial Intelligence Centre, the Independent Police Investigative Directorate, National Prosecuting Authority, the Hawks, Crime Intelligence and the SAPS [South African Police Service] Detective Service, South African Revenue Service, Special Investigating
Unit and the State Security Agency to investigate and prosecute COVID-related corruption. (n.p.)

The president further stated that these bodies were not just collaborating to investigate individual allegations in that they wanted to 'establish linkages between patronage networks' (Ramaphosa 2020). From this announcement and others, it is apparent that Covid-19-related corruption had highlighted a characteristic of corruption in South Africa: the role played by patronage. Even the health minister, Zweli Mkhize, has had to respond to allegations that persons within his network of friends and co-workers could have benefitted from irregular contracts related to the health department's response to the Covid-19 pandemic (De Villiers 2021).

As indicated in the study, Corruption and Development in Africa (Coolidge \& Rose-Ackerman 2003), it is unfortunately not a new phenomenon in Africa as various researchers have highlighted the role of patronage in corruption and its negative consequences on the socio-economic development process in Africa. The role of patronage in furthering corruption is not limited to South Africa or the African continent. In this article, the focus is, however, on reading the Bible in Africa, and therefore, the focus is on patronage-related corruption in African contexts. The phenomena has, however, been identified in counties as diverse as Russia (Ledeneva 2009), Columbia (Osborn 1968) and China (Wank 1996).

Considering the prevalence of corruption linked to patronage, African biblical scholars will need to engage with it in an overt manner in a post-pandemic future. The contribution that an analogous approach that compares the response of the New Testament to patronage in its socio-historical context and that of African biblical scholars will therefore be briefly explored in the following section. It is hoped that this engagement will contribute to the ongoing development of inculturation and postcolonial hermeneutics in a coronadefined Africa.

\section{Reflection on an African engagement with patronage}

When reflecting on contemporary examples of patronage in Africa, it is important to consider the cultural contexts in which it occurs and never from a Western perspective. It is furthermore important to take local contexts into consideration because anthropologist indicates that what is defined as corrupt by public authorities is often considered morally acceptable by various local populations (Graycar \& Jancsics 2017:1015). Local African practices must therefore in using a postcolonial and inculturation hermeneutic not simply be evaluated from the vantage point of a central political and social system, especially one that is based on those who underlie North American and Northern European societies. The latter can be described as universalist societies because they have an established central government and bureaucracy that are expected to enable equal access to state services (Moxnes 1991:243). 
Goods and services in universal societies are not regarded as favours, but as rights that the state is expected to provide to all who meet universal criteria (e.g. of education to children or a pension to the elderly). Furthermore, the concept of bureaucracy who underlie these societies according to Weber places the office at the heart of legal-rational activity in them (Graycar \& Jancsics 2017:1013). According to this view, civil servants hold an office and perform duties appropriate to it for which they receive a salary. They are not entitled to receive any other benefit for fulfilling their office and must follow specific rules that govern their offices that differ from those who regulate their family and friendship roles. One example of such a rule is that they must treat everyone impartially and equally. In modern rational-legal bureaucracies, the ideal social roles of officials thus cease to be defined in patronal terms. Patronage may, however, continue to exist covertly (Saller 1982:23).

As already mentioned, it is important from a postcolonial hermeneutical perspective that African social practices like patronage must be understood from an African ethical perspective, and not a contemporary Western one. It is, however, valuable to compare patronage in African contexts to analogous contexts like the 1st-century Greco-Roman world because it also does not reflect a contemporary Western world view which rejects patronage outright. In evaluating patron-client relations in analogous contexts, it should firstly be noted that patrons in these contexts provide social, economic and political resources to their clients as a special favour (Moxnes 1991:242-243). It is for this reason that they are considered unjust from a contemporary Western perspective that cannot envision societies in which patronage is the natural way of structuring social and political relations (Moxnes 1991:244). The situation is, however, different in contexts of economic and political oppression, exclusion and exploitation. In these circumstances, patronage often arises from the desperate need of clients to simply survive. This embrace of patronage is not restricted to the 1st-century Greco-Roman world, or contemporary African contexts. Graycar and Jancsics (2017:1016) identified a number of examples of contemporary trust-based informal exchange systems, such as compadrazgo in Latin America, blat in Russia and guanxi in China that compensate for the inadequacies of their society's formal institutional structures. These informal systems, which can be described as examples of fictive kinship or patronage (Ledeneva 2009:268; Osborn 1968:593; Wank 1996:820), are often labelled as corrupt by outside observers. There is thus often a difference between how outsiders and insiders in a culture evaluate patronage. An in-depth engagement with patronage, analogous to the New Testament engagement with it in its context, is therefore needed.

It firstly needs to be asked what the long-term effect of patronage is on a society in which it has become entrenched. Uslaner $(2017: 6,26)$ in this regard warns of the 'inequality trap' that is created when inequality and corruption become mutually reinforcing through patronage. In many societies, the poor become trapped as clients of patrons who claim most of their society's resources for themselves. By honouring the patrons, clients further increase their power and influence over the institutions on whom the poor depend for their livelihood. This leaves the poor with no option than to remain being their clients. On the other hand, others who are not necessarily desperately poor shun providing for themselves and instead rely on patrons for all their needs and thus become parasitic clients. Patronage can thus create an intricate socio-political system that intrenches corrupt practices and unethical conduct. Regarding political corruption, Fombad (2003:237), for example, states that in Cameroon in the 1990s, there was 'substantial patronage on offer between commercial and bureaucratic elites on the one hand and the ruling party circles on the other, who rely on and support each other'. The former Zaire provides another example of the creation of structures that benefit the leader (the patron), domestic associates (parasitic clients) and external sponsors (foreign partners) at the cost of ordinary people (Maipose 2003:93-94). Considering the situation in Nigeria, Jacqueline Coolidge and Rose-Ackerman (2003:75) come to a similar conclusion that 'Patron-client relationships have characterized all post-colonial regimes, military and civilian' and that this has hindered the transformation of the economy. This is evident in South Africa where patronagebased factional struggles have sabotaged efforts to address the social injustice and underdevelopment that characterise its economy (Beresford 2015:230). After examining the political, economic and social spheres of national life in Ghana and Zambia, Bertha and Kwaku Osei-Hwedie (2003:41) also found that one of the major contributing factors for the development and perseverance of corrupt practices in these contexts of unequal access to public resources is the existence of patron-client relationships. In view of the danger of patronage being harmful to all but a few elites and their selected clients, biblical scholars using inculturation hermeneutics should involve communities of ordinary people and their conceptual frame of reference in considering the New Testament's response to patronage. These communities should be encouraged to reflect on the danger of parasitic clients and exploitative patrons in their socialcultural contexts in view of the New Testament writers' response to analogous phenomena in their contexts (e.g. Th 1 $4: 10-12)$ and in their embodiment of faith.

Secondly, while Western exegetes tend to describe patronage mentioned in texts written in the 1st-century Mediterranean world in terms of 'rules', rather than 'relationships', contemporaries of these texts instead describe patron and client relationships not only in terms of business contracts, but also family relationships. This determined how practices like patronage were evaluated. While rules need to apply to all people at all times to be considered fair, relationships like those established by patronage are more flexible (Richards 2011:255). As indicated earlier, Paul, for example, did not consider the collection by the Gentiles for the poor in Jerusalem as settling a legal claim. He instead, as a patron, describes it as 
the fulfilment of a moral obligation within a relationship

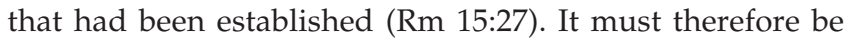
asked how patronage should be engaged with from the perspective of the core values, like Ubuntu, which govern relationships in African contexts. ${ }^{2}$ As an in-group practice, patronage can both divide communities and entrench corruption. Fombad (2003:255) has, for example, warned that 'The deep-seated ethnic, cultural and linguistic divisions within Cameroon have been exploited by the promoters of the corrupt system of patronage, favouritism and nepotism'. In South Africa, patronage struggles have resulted in intense factional struggles within the ruling party that has had a detrimental effect on service delivery (Beresford 2015:238240). The use of African values to engage with patronage by scholars should, like with those of other cultures, therefore be performed critically. Otaluka (2017) in his rigorous analysis of the causes, effects and possible solutions to the problem of corruption in Africa with special reference to nepotism has, for example, indicated that the existence of an extended family system in African societies often actively encourages nepotism. While nepotism, as in the 1st-century Mediterranean world (Richards 2011:253), is not considered a corrupt practice by many African communities because it makes sense to trust family members to manage their affairs rather than strangers, it has a detrimental effect on public institutions over time. In the 1980's, in Sierra Leone, for example, nepotism negatively impacted administrative efficiency in that it along with patronage resulted in the recruitment of incompetent individuals (Kpundeh 2003:206). This is also the case in Zambia, where nepotism and patronage based on ascriptive relationships rather than merit was a particular concern (Osei-Hwedie \& OseiHwedie 2003:42, 49-50, 54). According to Coolidge and Rose-Ackerman (2003:76), it has also led to the dire situation in Nigeria that 'deep divisions in societies that are reflected in strong patron-client links can, when combined with natural resource wealth, produce a pathological situation that feeds on itself'. These examples highlight the need for African communities to reflect carefully on the role played by brokers who provide access to public resources. In the South African context, brokers are often referred to as 'gatekeepers'. Gatekeepers use their positions of authority within the ruling party, or in public office, to control access to resources and opportunity. In this way, they maintain extensive patronage networks (Beresford 2015:238).

While brokers play a key role in providing access to those excluded from resources and opportunities, their role must be regulated by clear guidelines that differentiate between public and personal resources. In Roman society, the role of friends was, for example, not differentiated from that of public officials and therefore unlike in contemporary Western societies, political and personal relationships were intertwined. The exchange of favours and gifts was therefore not considered to be only appropriate in personal relationships (Moxnes 1991:245). Friendship in the ancient world also functioned as a social contract through which the well-connected elite would provide their 'friends' in the provinces access to the central administration (Moxnes 1991:245). In Universalistic societies, like in the contemporary Western world, giving preferential treatment to friends is considered a corrupt interference in the system of government (Moxnes 1991:245). The situation in Africa is, however, often more analogous to that of the Greco-Roman world in that brokers often use their ability to distribute public resources for their personal gain. In the 1980's Sierra Leone, the governing party, for example, used political patronage that increased the power of the politicians in that their client as civil servant was loyal to the patron as a person rather than as an administrator representing a government department (Kpundeh 2003:203). The opposite can also occur in that clients only consider their relationship with their brokers and patrons and not with the public entity they represent. An example of this is the role party patronage played in loan disbursement for agriculture at the Credit Organization of Zambia (COZ). As it considered an expression of patronage and not a legal contract, the loan recipients felt no compulsion to repay the loans that over time led to the demise of the organisation.

In response to the problems created by patronage, it must be taken into consideration that one way to escape the spiral of increasing inequality and corruption in Africa is to ensure that incomes and resources are distributed more equally. The systematic entrenchment of public patronage that enriches the elite at the expense of the poor therefore needs to be critiqued in the manner texts like Matthew 20:1-15 upends the entire patron-client system that dominated 1st-century Palestine. An example of the destructive effect of public patronage in Africa is the way the Nigerian government in the early 1980s resisted free trade reforms suggested by the International Monetary Fund apparently because the provision of import licensing was a major source of payments for the help of patrons (Coolidge \& Rose-Ackerman 2003:75). In these instances, the entire system of public patronage needs to be dismantled. Kpundeh (2003:214), for example, sees the creation of administrative systems that are 'relatively free' from patronage supervised by independent institutions as the only long-term solution to corruption in Sierra Leone. Independent institutions and the equal distribution of resources deny political leaders' opportunities to position themselves as patrons in a system of clientelistic politics (Uslaner 2017:82). As suggested by different New Testament writers, patronage that aids only a few harms the poor and strengthens exploitative patrons, should thus be challenged. This raises the question how this should be performed. While Crook (2012:66) uses the terms 'patron' and 'benefactor' interchangeably, he often uses patronage specifically to refer to acts that involve individual interaction, while benefaction refers to items given to collectivities in the Greco-Roman world. In this regard, the tentative differentiation between public benefaction and personal patronage in the Greco-Roman world can be used to reflect on how trust-based informal exchange systems can be conducted in an ethical manner in Africa. 
In his socio-historical studies, Joubert $(2000,2001)$ focussed on benefaction (or euergetism) and patronage in the ancient Greco-Roman world to determine if they are one or two different forms of social exchange. Most researchers, according to Joubert, use the terms patronage and euergetism interchangeably for the relationship between socially unequal individuals (or groups) in which an exchange of different resources occurs. Determining if they are the same type of exchange depends on the level of abstraction, the exchange is viewed because differences only become apparent on a lower level of abstraction (Joubert 2001:21, 24). For example, while in both patronage and benefaction, there is an exchange of goods and services that lead to mutual obligations between participants with different status, the content of the goods and the nature of the ensuing relationship are different. Specific forms of patronage like that of the emperor and the people of Rome were also in form and structure unique to the Roman world. Civic benefaction, because of its collective nature, also differed from patron-client relationships that entrenched the submissive role of the client (Joubert 2001:23). While other differences are more difficult to describe, Joubert argued that an important difference between benefaction (euergetism) and patronage is that the relationship established by benefaction is not exploitative (Crook 2012:61).

Crook (2012:60), who has closely engaged with Joubert's work, has pointed out the challenge one encounters when attempting to demarcate clearly between patronage and benefaction. While Crook (2012:64) agreed that patronage and benefaction are not exactly the same phenomena, he considers the difference between them to be far more subtle than Joubert has argued. While Joubert has argued that there is a large overlap between the two systems with the main difference being that unlike benefaction, patronage tended to be more political, exploitative and elitist. For Crook (2012:65), the difference is rather in the nature of the offering involved. Patronage usually occurred between individuals and involved day-to-day goods and opportunities needed by them to survive. Benefaction was more sporadic and focussed on luxury offerings (public buildings or games) for a group of people like a city or a country. For him, the personal nature of the relationship involving patronage made it prone to exploitation, even though this was not its defining characteristic (Crook 2012:65). It was simply easier to exploit an individual receiving patronage than a city receiving a benefit.

Even though the difference between patronage and benefaction is still debated regarding the Greco-Roman world, it should in view of the above be attempted to promote benefaction. Benefaction provides needed benefits for the good of all without expecting anything in return. It differs from patronage that is personal and that expects something in return. There should thus be a concerted effort made by the church to encourage those with the necessary means to act as benefactors of a society ravaged by Covid-19.
These benefactors should be guided by the question if their acts reflect the will of God and enhances the reputation of the church.

\section{Conclusion}

In this article, one of the prevalent forms of corruption, the misuse of patronage, has been engaged from the perspective that this phenomenon must not simply be condemned by the church from a Western cultural perspective. It needs to be engaged with in a thorough manner guided by the timely exegesis of the Bible to provide a contemporary ecclesiology that embodies faith in a corona-defined world. To do this, it needs to use a relevant, African hermeneutics. Therefore, this article explored the possibility of comparing the response of early Christian writers to patronage in the 1st century to analogous African contexts. This initial exploration has indicated that an analogous comparative approach has the potential to provide deeper insights in understanding the relationship established by patronage. In its engagement with patronage, the church must encourage its members to ask if it establishes parasitic or exploitative relations, if it is beneficial to the whole society over an extended period of time and if a clear distinction is made between public (offices) and personal resources. Ultimately, it needs to be asked if benefaction reflects the will of God and enhances the reputation of the congregation of God.

\section{Acknowledgements Competing interests}

The author declares that he has no financial or personal relationships that may have inappropriately influenced him in writing this article.

\section{Author's contributions}

M.J.N. is the sole author of this research article.

\section{Ethical considerations}

This article followed all ethical standards for research without direct contact with human or animal subjects.

\section{Funding information}

This research received no specific grant from any funding agency in the public, commercial or not-for-profit sectors.

\section{Data availability}

Date sharing is not applicable to this article as no new data were created or analysed in this study.

\section{Disclaimer}

The views and opinions expressed in this article are those of the author and do not necessarily reflect the official policy or position of any affiliated agency of the author. 


\section{References}

Barton, S.C., 2002, 'Social-scientific criticism', in S.E. Porter (ed.), Handbook to exegesis of the New Testament, pp. 277-290, Brill Academic, Boston, MA.

Basore, J.W., 1975, Seneca, moral essays, vol III: De Beneficiis, Heinemann, London.

Beresford, A., 2015, 'Power, patronage, and gatekeeper politics in South Africa', African Affairs 114(455), 226-248. https://doi.org/10.1093/afraf/adu083

Burrus, V., 2009, 'The gospel of Luke and the acts of the apostles', in F.F. Segovia \& R.S. Sugirtharajah (eds.), A postcolonial commentary on the New Testament writings, pp. 133-155, T \& T Clark, London.

Coolidge, J. \& Rose-Ackerman, S., 2003, 'Kleptocracy and reform in African regimes: Theory and examples', in K.R. Hope \& B.C. Chikulo (eds.), Corruption and development in Africa: Lessons from country case-studies, pp. 57-86, Palgrave, New York, NY.

Crook, Z.A., 2012, Reconceptualising conversion: Patronage, loyalty, and conversion in the religions of the Ancient Mediterranean, De Gruyter, Berlin.

DeSilva, D.A., 2004, 'Embodying the word: Social-scientific interpretation of the New Testament', in S. McKnight \& G.R. Osborne (eds.), The face of New Testament studies: A survey of recent research, pp. 118-129, Baker Academic, Grand Rapids, MI.

De Villiers, J., 2021, 'How Daily Maverick's digital vibes reports compare to Mkhize's responses', News24, 26 May 2021.

Fombad, C.M., 2003, 'Endemic corruption in Cameroon: Insights on consequences and control', in K.R. Hope \& B.C. Chikulo (eds.), Corruption and development in Africa: Lessons from country case-studies, pp. 234-260, Palgrave, New York, NY

Graycar, A. \& Jancsics, D., 2017, 'Gift giving and corruption', International Journal of Public Administration 40(12), 1013-1023. https://doi.org/10.1080/01900692.201 6.1177833

Holter, K., 2002, Old Testament research for Africa: A critical analysis and annotated bibliography of African Old Testament dissertations, 1967-2000, Peter Lang, New York, NY.

Hope, K.R. \& Chikulo, B.C., 2003, Corruption and development in Africa: Lessons from country case-studies, Palgrave, New York, NY.

Jonker, L.C., 2018, 'Further interrogation of the comparative paradigm in African biblical scholarship: Towards an analogical hermeneutics for interpreting the Old Testament in Africa', in J. Punt \& M.J. Nel (eds.), Reading writing right, pp. 1-28, Testament in Africa', in J.
Sun Media, Stellenbosch.

Joubert, S., 1999, “'Homo reciprocus:” Seneka, Paulus en weldoenerskap', HTS Teologiese Studies/Theological Studies 55(4), 1022-1038. https://doi. org/10.4102/hts.v55i4.1664

Joubert, S., 2000, Paul as benefactor: Reciprocity, strategy and theological reflection in Paul's collection, Mohr Siebeck, Tübingen.

Joubert, S.J., 2001, 'One form of social exchange or two? "Euergetism," patronage and Testament studies', Biblical Theology Bulletin 31(1), 17-25. https://doi. org/10.1177/014610790103100104

Kpundeh, S.J., 2003, 'Controlling corruption in Sierra Leone: An assessment of past efforts and suggestions for the future', in K.R. Hope \& B.C. Chikulo (eds.), Corruption and development in Africa: Lessons from country case-studies, pp. 198-217, Palgrave, New York, NY.

Ledeneva, A., 2009, 'From Russia with "Blat": Can informal networks help modernize Russia?', Social Research 76(1), 257-288.

MacMullen, R., 1990, Corruption and the decline of Rome, Yale University Press, New Haven, $\mathrm{CT}$.

Maipose, G.S., 2003, 'Aid abuse and mismanagement in Africa: Problems of accountability, transparency and ethical leadership', in K.R. Hope \& B.C. Chikulo (eds.), Corruption and development in Africa: Lessons from country case-studies, pp. 87-103, Palgrave, New York, NY.
Masenya, M., 2016, 'Ruminating on Justin S. Ukpong's inculturation hermeneutics and its implications for the study of African biblical hermeneutics today', HTS Teologiese Studies/Theological Studies 72(1), a3343. https://doi.org/10.4102/hts. v72i1.3343

Mashau, T.D., Thinandavha, D. \& Kgatle, M.S., 2019, 'Prosperity gospel and the culture of greed in post-colonial Africa: Constructing an alternative African Christian theology of Ubuntu', Verbum et Ecclesia 40(1), a1901. https://doi.org/10.4102/ ve.v40i1.1901

Mbamalu, A., 2013, 'Patronage and clientelism in the fourth gospel', In die Skriflig/In Luce Verbi 47(1), a657. https://doi.org/10.4102/ids.v47i1.657

Moxnes, H., 1991, 'Patron-client relations and the new community in Luke-Acts', in J.H. Neyrey (ed.), The social world of Luke-Acts: Models for interpretation, pp. 241-268, Hendrickson Publishers, Peabody, MA.

Osborn, A., 1968, 'Compadrazgo and patronage: A Colombian case', Man 3(4), 593-608. https://doi.org/10.2307/2798581

Osei-Hwedie, B.Z. \& Osei-Hwedie, K., 2003, 'The political, economic, and cultural bases of corruption in Africa', in K.R. Hope \& B.C. Chikulo (eds.), Corruption and development in Africa: Lessons from country case-studies, pp. 40-57, Palgrave, New York, NY.

Otaluka, W.O., 2017, 'The cultural roots of corruption: an ethical investigation with particular reference to nepotism', PhD thesis, University of KwaZulu-Natal.

Ramaphosa, M.C., 2020, COVID-19, South African Government: From the desk of the president, s.n., s.I.

Richards, E.R., 2011, '(Mis)reading Paul through western eyes', in T.J. Burke \& B.S. Rosner (eds.), Paul as missionary: Identity, activity, theology and practice: Library of New Testament studies, pp. 247-263, T \& T Clark, London.

Saller, R.P., 1982, Personal patronage under the early empire, Cambridge University Press, Cambridge.

Scott, B.B., 2007, 'The reappearance of parables', in E.F. Beutner (ed.), Listening to the parables of Jesus: Jesus seminar guides, pp. 95-119, Polebridge Press, Santa Rosa, CA.

Sell, H.T., 1998, Studies in early church history, Woodlawn Electronic Publishing, Willow Grove, PA.

Ukpong, J.S., 2001, 'New Testament hermeneutics in Africa: Challenges and possibilities', Neotestamentica 35(1/2), 147-167.

Ukpong, J.S., 2002, Reading the bible in the global village: Cape Town, Society of Biblical Literature, Atlanta, GA.

Uslaner, E.M., 2017, The historical roots of corruption mass education, economic inequality, and state capacity, Cambridge University Press, Cambridge.

Van Eck, E. \& Kloppenborg, J.S., 2015, 'An unexpected patron: A social-scientific and realistic reading of the parable of the Vineyard Labourers (Mt 20:1-15)', HTS Teologiese Studies/Theological Studies 71(1), a2883. https://doi.org/10.4102/hts. v71i1.2883

Wank, D.L., 1996, 'The institutional process of market clientelism: Guanxi and private business in a South China City', The China Quarterly 147, 820-838. https://doi. org/10.1017/S030574100005181X

West, G.O., 2008, 'Interrogating the comparative paradigm in African biblical scholarship', in H. De Wit \& G.O. West (eds.), African and European readers of the bible in dialogue: In quest of a shared meaning, pp. 37-64, Brill, Leiden.

West, G.O., 2018, 'African biblical scholarship as post-colonial, tri-polar, and a site-ofstruggle', in T.-S.B. Liew (ed.), Present and future of biblical studies: Celebrating 25 years of Brill's 'biblical interpretation', pp. 240-273, Brill, Leiden.

Winter, B.W., 1994, Seek the welfare of the city: Christians as benefactors and citizens, Eerdmans, Grand Rapids, MI. 